\title{
A Probe into Rural Households' Food Accessibility Scenario: A Micro Level Study in West Bengal
}

\author{
Shibani Bagchi ${ }^{1 *}$ and Archita Ghosh ${ }^{2}$ \\ ${ }^{1}$ Associate Professor of Economics, City College of Commerce \& Business Administration, Kolkata, India \\ ${ }^{2}$ Professor of Economics, University of Kalyani, West Bengal, India \\ Corresponding author: shibani.santiniketan@gmail.com
}

\begin{abstract}
Food security is recognized as a basic human right and in the 'Sustainable Development Summit' of 2015, achieving 'Zero Hunger' by 2030 has been set as one of the 17 sustainable development goals. The incidence of hunger is very much region or context-specific. India remains at 'serious' category in Global Hunger Index Severity Scale, 2017. Food accessibility being the most important pillar of food security, in this paper we attempt to assess the incidence, depth and severity of food inaccessibility at the household level in three villages of the district of Birbhum, West Bengal. The study, based on primary data covering 257 households, also intends to examine food accessibility of the households classified by their primary source of income. We have taken monthly per capita consumption expenditure (MPCE) on food as the indicator of food accessibility. The MPCE on food as per the minimum food basket set by the Planning Commission in 2014 and the mean MPCE on food for rural West Bengal as determined by the NSSO in 2011 are considered as two threshold levels. The study reveals the alarming reality that a significant percentage of households with zero operational land and marginal farmers do not have food accessibility. An inquiry into the sources of income of the households reveals that there exists (i) a negative relation between wage income and food accessibility, (ii) an inverse relation between income generated from farm activity and food accessibility and (iii) a positive relation between income from regular service, trade, business and food accessibility.
\end{abstract}

Keywords: Global Hunger Index, Minimum Food Basket, Monthly per capita consumption expenditure on food, Food Inaccessibility gap.

The concept of 'food access' is derived from the concept of 'food security'. It represents the ability of a household or an individual to acquire food through one or a combination of production, purchases, barter, gifts, borrowing, or food aid. It is an important component of food security, which has been recognized as a basic human right long back in the Article 25(1) of the Universal Declaration of Human Rights of 1948. Since then, in several international agreements, there has been a general consensus among the nations that provision of this basic human right would be the primary responsibility of the States towards their citizens. At an historic UN Summit in September 2015, 193 UN Members unanimously agreed to achieve 'Zero Hunger' by 2030 as one of the 17 New Sustainable
Development Goals (SDGs). The aim of the goal of 'Zero hunger' is to end all forms of hunger and malnutrition by 2030, making sure all people especially children and the more vulnerable - have access to sufficient and nutritious food all the year round.

India has been signatory to many international treaties for ensuring food security. However, according to the Global Hunger Index (GHI), 2017, which ranked countries based on four key indicators, viz. undernourishment, child mortality, child wasting and child stunting, India had a "serious" hunger problem and ranked 100th out of 119 countries on the global hunger index.

Although GHI has been updated once a year, unfortunately, in India, such regular, systematic 
attempt at the sub-national or sub-state level has been lacking. Such district level analysis can be particularly helpful in targeting programs. The M.S Swaminathan Research Foundation (MSSRF) and the UN World Food Programme (WFP) published various food security atlases for rural as well as for urban India. The Institute for Human Development (IHD) on behalf of the WFP analysed the dimensions of food security at the sub-state or district level, for 8 states of India - Orissa, Jharkhand, Chhattisgarh, Madhya Pradesh, Rajasthan, Bihar, Uttar Pradesh and Maharashtra. But, unfortunately, no specific consolidated study on food security at the districtlevel was conducted for West Bengal, where the level of hunger was alarming according to India State Hunger Index (ISHI), 2009 as developed by International Food Policy Research Institute (IFPRI) ${ }^{1}$. Moreover, according to NSSO's latest available published report on Perceived Adequacy of Food Consumption in Indian Households (2013), the percentage of households not perceiving themselves as getting adequate food throughout the year was the highest $(4.6 \%)$ in West Bengal among all the States in India, followed by Orissa (4.0\%), whereas in rural India the same percentage was $2.1 \%$ or less in all the major States.

All these facts necessitate in depth probing on different aspects of food security in West Bengal, particularly in the absence of adequate consolidated study at the district level. Loka Kalyan Parishad (2011), however, made an empirical study of the on-going Decentralized Initiative in West Bengal to combat Poverty and Hunger in six districts of the State, viz. Cooch Behar, Jalpaiguri, Uttar Dinajpur, Murshidabad, Birbhum and Purulia. Moreover, several individual studies on food security in different districts have been taken up.

In the case of Birbhum district, previous microlevel studies focussed on food availability status in relation to population growth and measure incidence, depth and severity of food insecurity. It appears that there has been, so far, no study of the district of Birbhum, solely on the dimension of food accessibility which may be regarded as the axis of food security around which all economic activities revolves for ultimately acquiring food

${ }^{1}$ IFPRI in 2009 developed for the first time India State Hunger Index (ISHI) for 17 states in India, covering more than 95 percent of the population. and other basic necessities of life. It is against this background that the present study is undertaken to analyse food accessibility of households in three villages of Birbhum district where the per cent of rural population as per 2011 Census is 87.17. Since the incidence of poverty is acute in rural areas and the MSSRF report of 2008 warned that the high economic growth rates have failed to improve food security particularly in the rural economy of India, the present study concentrates on rural areas. The study is based on primary data collected from field survey carried out in February-March, 2018, covering 257 households comprising different socio-economic classes based on their operational holdings.

In the second section of the paper, a brief review of literature on the subject is presented. The third section is concerned with the objectives of the study and methodology adopted for the field survey; the fourth section analyses various results relating to our study. The fifth section presents the conclusion of the study.

\section{Review of Literature}

Food access being one important pillar of food security, literature on this concept is intertwined with those of 'food security'. Food security in the 1970s used to be visualised as the availability at all times of adequate world supplies of basic foodstuffs to sustain a steady expansion of food consumption and to offset fluctuations in production and prices (United Nations, 1975). The occurrence of famines was visualised as the result of food availability decline, which was known as FAD approach.

Sen, A (1981) challenged the FAD paradigm and pioneered the idea that starvation 'is not the characteristic of there being not enough food to eat......' He categorically analysed that an individual is compelled to face a situation of starvation if he does not have the adequate ability to access food, rather than because of shortfall in food availability. Sen (1987) further elaborated the concept of food accessibility: 'the failure of a person to command food in a market economy can arise from' 'a "pull failure" if the person loses his ability to demand food in the market, e.g., through loss of employment and the resulting loss of purchasing power.' 
Food and Agriculture Organisation in 1983 stated that food security means 'ensuring that all people at all times have both physical and economic access to the basic food they need' (M.S Swaminathan Research Foundation and The World Food Programme, 2008, page 4). In 1986, the World Bank elaborated this concept of food security as 'access by all people at all times to enough food for an active and healthy life'.

Different scholars also formulated the concept of food access. Riely et al. (1995) explained that food access is ensured when communities and households and all individuals within them have adequate resources, such as money, to obtain appropriate foods for a nutritious diet, vide Robert et al. (2013). According to Sajjad and Iffat (2014), food accessibility may be considered as the axis of food security around which all the economic activities revolve either by growing food directly under primary economic activity or through earning money finally to buy food through secondary or tertiary economic activities.

There is also vast literature on the measurement of food accessibility. In fact, food access being one major component of food security, all literature on measurement of food security naturally encompasses that on food access. In the literature, incidence, depth and severity of food insecurity have been measured in terms of head count ratio, food insecurity gap and squared food insecurity gap along the lines of well established poverty measure provided by Foster, Greer and Thorbecke (1984). For example, Appleton (1999), while examining the welfare of the women headed households in Uganda applied these measures. Using food security self-assessment data from the national survey administered by the United States Department of Agriculture, Dutta and Gundersen (2007) proposed calculation of alternative indices for food security with the help of Foster, Greer and Thorbecke measures and by Sen's measure (1976). Orewa and Iyangbe (2009) assessed the degree of food insecurity in Nigeria by examining the food insecurity profile among the rural and low-income urban population in the country using Foster, Greer and Thorbecke measures. Guja (2012), in a study to measure the rural households' food security status in Ethiopia, and Muche et al. (2014), for rural households of Southwest Ethiopia, analysed the extent of food insecurity in terms of Foster, Greer and Thorbecke measures. Jabo et al. (2014) examined the incidence, depth and severity of food insecurity among rural households in Nigeria with the help of those measures. Karmakar and Sarkar (2014), intending to study the nature of income inequalities, food security and poverty among different sub-groups of population in West Bengal, measured the food gap from the minimum food requirement to attain food security applying the same measures. Abu and Soom (2016), in course of examining factors affecting household food security status among farming households of Benue State, Nigeria, estimated the head count ratio, food insecurity gap by means of Foster, Greer and Thorbecke measures. Ahmed et al. (2017), while analysing food security of small farming households of rural Pakistan, also used the same measures.

Food access can be measured either at the household or at individual level. In the present study, which makes an attempt to analyse household level food accessibility, all the above measures have been applied for estimating the incidence, depth and severity of the food inaccessibility of the households.

\section{Objectives}

The precise objectives of the study are:

(i) to assess the incidence, depth and severity of food inaccessibility at the household level across the socio-economic classes.

(ii) to examine food accessibility of the households classified by their primary source of income.

\section{Database and Methodology}

Food accessibility of the households has been analysed in terms of their monthly per capita consumption expenditure (MPCE) on food from all sources. The concept of MPCE at the household level, as defined by the NSSO, has been followed in our study. The households' requirement of food expenditure is measured in terms of (i) the MPCE on food as per the minimum food basket for rural India set by the Planning Commission in 2014, which is the latest available official estimate during the period of our survey, adjusted by the latest consumer price index published by the Central Statistical Organization (CSO) and (ii) the mean MPCE on food of rural West Bengal, determined 
by NSSO in 2011, adjusted by the latest consumer price index.

The study is based on primary data collected from field survey in three selected villages of the district chosen. A multistage stratified random sampling method has been adopted in the selection of the final sample. In the first stage, the district of Birbhum has been selected randomly among the districts of West Bengal, having more than 85 per cent of rural population, as per 2011 Census. In the second stage, among the different blocks of the district, Bolpur-Sriniketan block has been chosen randomly. Three villages from the block, each having at least 125 households, have been selected. At the final stage of the sampling procedure, households in each village have been stratified into two groups, viz., landed and landless. Landed households and landless households have been selected randomly in proportion to their share in total households to arrive at the final sample for the study. The landed households have been stratified into five standard land size groups viz., marginal, small, semi-medium, medium and large.

A stratified random sample of farmers from different land size groups is drawn giving proportional allocation in respect of operational land ${ }^{2}$ size classification. Again each class of landless and landed households has been taken randomly according to various castes in proportion to their share in total households. A 40 per cent sample of households has been drawn in each village. The total sample size is 257 .

A questionnaire, designed to elicit information on socio-economic status and the detailed consumption pattern of the households, has been prepared. The technique of Mixed Recall Period, as followed by the NSSO, has been used for collecting information on household's consumption.

\section{RESULTS AND DISCUSSION}

Following the existing literature, we have used Head Count Ratio, Total Food Inaccessibility Gap and Squared Food Inaccessibility Gap as the measures of incidence, depth and severity of food accessibility respectively.

Head count ratio measures the percentage of

${ }^{2}$ Operational land is defined as the sum of Land Owned + Land Leased In+Land Assigned + Current Fallow-Land Leased Out. incidence, i.e., the proportion of people who do not have food accessibility in total population.

Food Inaccessibility Gap of the $i^{\text {th }}$ household (FIGi) is defined as:

$$
F I G_{i}=\left(M P C E F R-M P C E F I_{i}\right) / M P C E F R
$$

MPCEFR = Monthly per capita consumption expenditure on food required by the households not having food accessibility

MPCEFI $_{i}=$ Monthly per capita consumption expenditure on food incurred by the $i^{\text {th }}$ household not having food accessibility.

Total Food Inaccessibility Gap (TFIG), which indicates the depth of food inaccessibility among the households not having food accessibility, is expressed by

$$
T F I G=\sum_{i=1}^{m} F I G_{l} / m
$$

where, $m$ is the number of households not having food accessibility.

The Squared Food Inaccessibility Gap (SFIG) indicates severity of food inaccessibility among the households who do not have food accessibility, i.e., the extent to which the MPCE on food of the respective households falls below the predetermined threshold. It is given by

$$
(S F I G)=\sum_{i=1}^{m}\left(F I G_{i}\right)^{2} / m
$$

Table 1 represents all these measures of food inaccessibility when the threshold for food accessibility is MPCE on food as per the minimum food basket for rural India. The study reveals that the head count ratio of food accessibility in the survey region is 0.1533 , i.e. $15.33 \%$ households' MPCE on food is less than that for the minimum food basket for rural India set by the Planning Commission in 2014, adjusted by the latest consumer price index. The total food inaccessibility gap, measuring the depth of food inaccessibility, is 0.15 and the squared food inaccessibility gap, indicating severity of food inaccessibility, is 0.03 .

The same measures in respect of the mean MPCE on food for rural West Bengal are presented in Table 2. The head count ratio of food inaccessibility (0.533), 
the total food inaccessibility gap (0.19) and the squared food inaccessibility gap (0.05) are all higher, in contrast to those when the threshold is measured by the MPCE on food as per the minimum food basket for rural India. This is quite natural, since the mean MPCE on food of any state is expected to be at a much higher level than that as per the minimum food basket for the country as a whole. But, what is alarming for policy consideration is that MPCE on food of $53.33 \%$ of households fall below the mean of that of rural West Bengal in the respective villages of a block of the district of Birbhum, where the cropping intensity is higher than that of the district's average.

Table 1: Measures of Food Inaccessibility

\begin{tabular}{cc}
\hline Type of Measures & Villages Combined \\
\hline Head Count Ratio & 0.1533 \\
Total Food Inaccessibility Gap & 0.1500 \\
Squared Food Inaccessibility Gap & 0.0307 \\
\hline
\end{tabular}

Source: Authors' calculation based on data obtained from the field survey.

Note: The threshold for food access being MPCE on food as per the minimum food basket for rural India.

Table 2: Measures of Food Inaccessibility

\begin{tabular}{cc}
\hline Type of Measures & Villages Combined \\
Head Count Ratio & 0.5333 \\
Total Food Inaccessibility Gap & 0.1955 \\
Squared Food Inaccessibility Gap & 0.0556 \\
\hline
\end{tabular}

Source: Authors' calculation based on data obtained from the field survey.

Note: The threshold for food access being the mean MPCE on food of Rural West Bengal.

Table 3 depicts various results from our field survey related to the extent of food inaccessibility across different land-size classes when compared with the MPCE as per the minimum food basket for rural India. It is clear from the table that the situation of insecure food access is faced only by households with zero operational land and also by the marginal farmers. The MPCE on food of all the households belonging to other land-size classes are thus found to be greater than that as per the minimum food basket for rural India. $16.13 \%$ of households with zero operational land do not have food access, whereas the same percentage for marginal farmers was 18.37. It should be noted that the households with zero operational land and the marginal farmers constitute $86 \%$ of the population in the study region. The total food inaccessibility gap and the squared food inaccessibility gap are higher in case of marginal farmers ( 0.152 and 0.032 respectively) than those of the households with zero operational land ( 0.143 and 0.028 respectively).

Table 3: Land-Size-Class wise Measures of Food Inaccessibility

\begin{tabular}{cccc}
\hline \multicolumn{4}{c}{ Villages Combined } \\
\hline $\begin{array}{c}\text { Operational } \\
\text { Land Size } \\
\text { Class }\end{array}$ & $\begin{array}{c}\text { Head } \\
\text { Count } \\
\text { Ratio }\end{array}$ & $\begin{array}{c}\text { Total Food } \\
\text { Inaccessibility } \\
\text { Gap }\end{array}$ & $\begin{array}{c}\text { Squared Food } \\
\text { Inaccessibility } \\
\text { Gap }\end{array}$ \\
\hline $\begin{array}{c}\text { Households } \\
\text { with Zero }\end{array}$ & 0.1613 & 0.1426 & 0.0277 \\
Operational & & & \\
Land & & & \\
Marginal & 0.1837 & 0.1520 & 0.0316 \\
Small & 0 & Not Applicable & Not Applicable \\
Semi- & 0 & Not Applicable & Not Applicable \\
Medium & & & \\
Medium & 0 & Not Applicable & Not Applicable \\
Big & 0 & Not Applicable & Not Applicable \\
\hline
\end{tabular}

Source: Authors' calculation based on data obtained from the field survey.

Note: The threshold for food access being MPCE on food as per the minimum food basket for rural India.

Table 4: Land-Size-Class wise Measures of Food Inaccessibility

\begin{tabular}{cccc}
\hline \multicolumn{4}{c}{ Villages Combined } \\
\hline $\begin{array}{c}\text { Operational } \\
\text { Land } \\
\text { Size Class }\end{array}$ & $\begin{array}{c}\text { Head } \\
\text { Count } \\
\text { Ratio }\end{array}$ & $\begin{array}{c}\text { Total Food } \\
\text { Inaccessibility } \\
\text { Gap }\end{array}$ & $\begin{array}{c}\text { Squared Food } \\
\text { Inaccessibility } \\
\text { Gap }\end{array}$ \\
\hline $\begin{array}{c}\text { Households } \\
\text { with Zero }\end{array}$ & 0.6129 & 0.1951 & 0.0524 \\
Operational \\
Land
\end{tabular}

Source: Authors' calculation based on data obtained from the field survey.

Note: The threshold for food access being MPCE on food as per the mean MPCE on food of Rural West Bengal.

When compared with the mean MPCE on food of rural West Bengal (Table 4), it is observed that 
only the semi-medium, medium and big farmers are secured in terms of food access. Head count ratio of food inaccessibility of the households with zero operational land are the highest (0.6129) followed by that of the marginal farmers (0.5612) and small farmers (0.5). Thus there exists an inverse relation between land size and head-count ratio of households' food access. The depth and severity of food inaccessibility are the highest for the marginal farmers followed by that of the households with zero operational land and small farmers.

Our study also measures the incidence of food accessibility of the households classified by their castes. The findings are depicted in Tables 5 and 6 .

Table 5: Measures of Food Inaccessibility by Caste

\begin{tabular}{cccc}
\hline $\begin{array}{c}\text { Caste of } \\
\text { the House- } \\
\text { holds }\end{array}$ & $\begin{array}{c}\text { Head } \\
\text { Count } \\
\text { Ratio }\end{array}$ & $\begin{array}{c}\text { Total Food } \\
\text { Inaccessibility } \\
\text { Gap }\end{array}$ & $\begin{array}{c}\text { Squared Food } \\
\text { Inaccessibility } \\
\text { Gap }\end{array}$ \\
\hline GC & 0.0465 & 0.2019 & 0.0424 \\
SC & 0.1754 & 0.1095 & 0.0207 \\
$S T$ & 0.2619 & 0.1773 & 0.0377 \\
$O B C$ & 0 & Not Applicable & Not Applicable \\
\hline
\end{tabular}

Source: Authors' calculation based on data obtained from the field survey.

Note: The threshold for food access being MPCE on food as per the minimum food basket for rural India.

Table 6: Measures of Food Inaccessibility by Caste

\begin{tabular}{cccc}
\hline \multicolumn{4}{c}{ Villages Combined } \\
\hline $\begin{array}{c}\text { House- } \\
\text { hold's } \\
\text { Caste }\end{array}$ & $\begin{array}{c}\text { Head } \\
\text { Count } \\
\text { Ratio }\end{array}$ & $\begin{array}{c}\text { Total Food } \\
\text { Inaccessibility }\end{array}$ & $\begin{array}{c}\text { Squared Food } \\
\text { Inaccessibility }\end{array}$ \\
\hline GC & 0.2326 & 0.1685 & 0.0480 \\
SC & 0.5789 & 0.1873 & 0.0505 \\
ST & 0.7619 & 0.2213 & 0.0679 \\
OBC & 0.625 & 0.1380 & 0.0255 \\
\hline
\end{tabular}

Source: Authors' calculation based on data obtained from the field survey.

Note: The threshold for food access being MPCE on food as per the mean MPCE on food of Rural West Bengal.

Insecurity in terms of food access is found to be highest among the ST population $(26.19 \%)$, followed by the SCs $(17.54 \%)$, if the MPCE on food as per the minimum food basket for rural India is considered to be the threshold of food accessibility. $04.65 \%$ of households belonging to general caste (GC) have to face the situation of insecurity in terms of food access by the same cut off. All the households from OBC category have food accessibility. However, it is observed that the depth and severity of food inaccessibility is the highest among the GC $(0.201$ and 0.042$)$ followed by ST (0.177 and 0.037$)$ and SC (0.109 and 0.020).

If we assess the households' food accessibility in terms of the mean MPCE on food of rural West Bengal, the situation is bleaker. This is evident from Table 6. It is quite alarming to find that the MPCE on food of $76.19 \%$ of ST households and that of $57.89 \%$ of SC households are less than the mean MPCE on food of rural West Bengal. More than 23\% of GC households and $6.25 \%$ of OBC households do not have food accessibility. The depth and severity of food inaccessibility is more for ST $(0.2213$ and $0.0679)$ and SC (0.1873 and 0.0505) than for GC (0.1685 and 0.0480) and OBC (0.1380 \& 0.0255). It is thus quite evident that ST and SC households are the most insecure in terms of food access.

On the whole, the total picture of households' food accessibility is gloomy in Bolpur -Sriniketan block of the district of Birbhum, which is supposed to be a developed one in terms of cropping intensity. High cropping intensity is supposed to generate higher income for those dependent on agriculture and other farm related activities. We have seen that rural people owning a small amount of land or no land are food insecure in large numbers. An in -depth probing into the source of households' income thus becomes essential.

The primary sources of income of the households classified in terms of the minimum food basket for rural India and on the basis of the mean MPCE on food of rural West Bengal are analysed in Table 7. There is, in fact, only one labourer in our sample, who earns his primary income from NREG activity, but he does not have food access, if the threshold is taken as the MPCE on food as per the minimum food basket for rural India. Among the farm casual labourers, $22.5 \%$ do not have food accessibility. More than $21 \%$ of households, who earn their primary income from trade and business, suffer from insecurity in terms of food access. Various trade and business activities of households are selling of vegetables, different livestock products, fish, pesticides, flowers, rural handicrafts, having groceries in villages, involved in dealership of ration. $14.29 \%$ cultivators' MPCE on food fall 
Table 7: Food Accessibility within each class of households classified by their primary source of income

\begin{tabular}{ccc}
\hline \multirow{2}{*}{ Primary Source of Income } & \multicolumn{2}{c}{ Villages Combined } \\
\cline { 2 - 3 } & $\begin{array}{c}\text { Households (\%) with MPCE on food < MPCE as } \\
\text { per the minimum food basket for rural India }\end{array}$ & $\begin{array}{c}\text { Households (\%) with MPCE on food }<\text { the } \\
\text { mean MPCE on Food of rural West Bengal }\end{array}$ \\
\hline Farm Casual Labour & 22.5 & 67.5 \\
Non-Farm Casual Labour & 11.43 & 65.71 \\
NREGA Labour & 100.00 & 100.00 \\
Cultivator & 14.29 & 66.67 \\
Trade \& Business & 21.43 & 21.43 \\
Service & 10.00 & 33.33 \\
Others & 11.11 & 22.22 \\
\hline
\end{tabular}

Source: Authors' calculation based on data obtained from the field survey.

Note: The threshold for food access being MPCE on food as per the minimum food basket for rural India \& MPCE on food as per the mean MPCE on food of Rural West Bengal.

below the MPCE on food as per the minimum food basket for rural India. More than $11 \%$ of nonfarm casual labourers and households engaged in other activities like brokery, pisiculture, serving as caretakers, hiring out farm implements, playing drums, performing folk song, serving as priests, are confronted with insecurity in terms of food access. It appears strange to note that even $10 \%$ of the service holders, among whom some are employed in schools, some in anganwadi centres, some in railway services, hospitals, in different small private companies, are insecure in terms of food access. However, this is possible when the family sizes of these households are large or the employment is casual in nature. Nevertheless, it remains a fact that service holders have the highest food accessibility, followed by that of the households engaged in other activities and non-farm casual labourers. Various non-farm activities where these households are engaged as casual labourers are construction related activity, plumbing, wood work, transport activity, serving as maid or cook in others' house. Other than the NREG labourer, the insecurity in terms of food access is the highest among the farm casual labourers, followed by that of the households involved in petty trade and business.

If the mean MPCE on food for rural West Bengal is taken as the threshold for food access, the entire situation is far more disappointing. This may be due to the fact that the mean MPCE on food of rural West Bengal is at a much higher level than that as per the minimum food basket for the country as a whole. Other than the only NREG labour, food access is the least among the farm casual labourers, followed by that of the cultivators and that of nonfarm casual labourers. In contrast, food accessibility is the highest among the households engaged in trade and business, followed by that of the households involved in other activities, and that of the service holders. Thus, involvement in business and in other activities as well as employment in service has a positive influence on food accessibility. On the other hand, it is quite surprising to observe that involvement in farm sector has a negative impact on food accessibility in the sample villages, which are under such a block where the cropping intensity is higher than the district's average. This obviously is a matter of concern and raises question about the distribution/marketing of the agricultural produce.

All these facts reveal that quantum of food accessibility primarily depends on the nature as well as quality of one's employment. This is why the share of households' annual income from different sources are now being analysed with the help of the tables 8 and 9. It is quite evident from Table 8 that the total wage income from farm as well as from non-farm sector (including income from NREGA) is higher for the households who do not have the food access in terms of the minimum food basket for rural India (48.63\%) in comparison to that for the household having food access (27.01\%). Moreover, a significant share of the annual income of the households, having MPCE on food less than that as per the minimum food basket for rural India, comes from agricultural wage income(35.76\%), followed by 
Table 8: Share of Annual Income of Households Classified by Their MPCE on Food Compared to the MPCE on Food as per the Minimum Food Basket for Rural India

\begin{tabular}{|c|c|c|c|c|c|c|c|}
\hline \multirow{3}{*}{$\begin{array}{l}\text { Household Category on } \\
\text { the basis of their } \\
\text { MPCE on Food }\end{array}$} & \multicolumn{5}{|c|}{ Villages Combined } & & \\
\hline & \multicolumn{7}{|c|}{ Share of Households' Annual Income } \\
\hline & $\begin{array}{c}\text { Agricultural } \\
\text { Wage Income }\end{array}$ & $\begin{array}{c}\text { Non } \\
\text { Agricultural } \\
\text { Wage Income }\end{array}$ & $\begin{array}{l}\text { NREGA } \\
\text { Income }\end{array}$ & $\begin{array}{c}\text { Income from } \\
\text { Farm } \\
\text { Production }\end{array}$ & $\begin{array}{c}\begin{array}{c}\text { Income } \\
\text { from } \\
\text { Service }\end{array} \\
\end{array}$ & $\begin{array}{c}\text { Income from } \\
\text { Trade/ } \\
\text { Business }\end{array}$ & $\begin{array}{l}\text { Income } \\
\text { from Other } \\
\text { Sources }\end{array}$ \\
\hline $\begin{array}{c}\text { Households with MPCE } \\
\text { on food }<\text { MPCE as per the } \\
\text { minimum food basket for } \\
\text { rural India }\end{array}$ & 35.76 & 07.95 & 04.92 & 13.70 & 18.56 & 07.35 & 11.75 \\
\hline $\begin{array}{l}\text { Households with } \\
\text { MPCE on food > MPCE } \\
\text { as per the minimum food } \\
\text { basket for rural India }\end{array}$ & 14.21 & 09.11 & 03.69 & 20.36 & 32.38 & 10.18 & 10.07 \\
\hline
\end{tabular}

Source: Authors' calculation based on data obtained from the field survey.

Table 9: Share of Annual Income of Households Classified by Their MPCE on Food Compared to the Mean MPCE on Food of Rural West Bengal

\begin{tabular}{|c|c|c|c|c|c|c|c|}
\hline \multirow{3}{*}{$\begin{array}{l}\text { Household Category on the } \\
\text { basis of their MPCE on Food }\end{array}$} & \multicolumn{6}{|c|}{ Villages Combined } & \\
\hline & \multicolumn{7}{|c|}{ Share of Households' Annual Income } \\
\hline & $\begin{array}{c}\text { Agricultural } \\
\text { Wage Income }\end{array}$ & $\begin{array}{c}\text { Non } \\
\text { Agricultural } \\
\text { Wage Income }\end{array}$ & $\begin{array}{l}\text { NREGA } \\
\text { Income }\end{array}$ & $\begin{array}{l}\text { Income from } \\
\text { Farm } \\
\text { Production }\end{array}$ & $\begin{array}{l}\text { Income } \\
\text { from } \\
\text { Service }\end{array}$ & $\begin{array}{l}\text { Income from } \\
\text { Trade/ } \\
\text { Business }\end{array}$ & $\begin{array}{l}\text { Income } \\
\text { from Other } \\
\text { Sources }\end{array}$ \\
\hline $\begin{array}{l}\text { Households with MPCE on } \\
\text { food < the Mean MPCE on } \\
\text { Food of Rural West Bengal }\end{array}$ & 28.77 & 12.50 & 05.35 & 16.84 & 20.99 & 05.62 & 09.94 \\
\hline $\begin{array}{l}\text { Households with MPCE on } \\
\text { food }>\text { the Mean MPCE on } \\
\text { Food of Rural West Bengal }\end{array}$ & 08.84 & 06.66 & 02.84 & 21.38 & 37.17 & 12.62 & 10.48 \\
\hline
\end{tabular}

Source: Authors' calculation based on data obtained from the field survey.

service income $(18.56 \%)$ and farm income $(13.70 \%)$. For households, having MPCE on food more than that as per the minimum food basket for rural India, income from service has the highest share in total annual income $(32.38 \%)$, followed by farm income $(20.36 \%)$ and agricultural wage income (14.21\%). If the agricultural wage income and farm income are considered together, it is observed that, it has a share of $49.46 \%$ in the total annual income of the households, not having food accessibility in terms of the minimum food basket for rural India, but a share of $34.57 \%$ in the total annual income of the households having food accessibility by the same criterion. On the other hand, if service income and income from trade and business are clubbed together, the result from our field survey shows that their shares in total income of the households facing the situation of insecurity in terms of food access and not facing that are $25.91 \%$ and $42.56 \%$ respectively. Thus, households, whose earnings are not primarily agriculture-based, have greater food access. This may be due to the fact that agricultural income has a component of uncertainty on account of which its variation is large.

Table 9 provides a picture of the share of annual income of the households classified with reference to the mean MPCE on food of rural West Bengal. The study reveals that wage income from farm as well as from non-farm activities including income under NREGA constitutes about $46.62 \%$ of total annual income of the households who are insecure with respect to food access, if the mean MPCE on food of rural West Bengal are used as a threshold for food accessibility. In contrast, the corresponding figure for the households having food accessibility 
by the same measure is only $18.34 \%$. This finding therefore indicates a negative relation between wage income and food accessibility. If agricultural wage income and income from farm production are considered at a time, its share in total annual income amounts to $45.61 \%$ for the households whose MPCE on food is less than the mean of that of rural West Bengal and $30.22 \%$ for those with MPCE on food being more than the mean of that of rural West Bengal. Thus an inverse relationship is observed between income generated from farm activity and household's food accessibility. In contrast, if income from service and that from trade and business are counted together, their share in total annual income of the households for the two groups, i.e. not having food access and having that in terms of the mean MPCE on food of rural West Bengal, are 26.61\% and $49.79 \%$ respectively. A positive relation between income from service, trade and food accessibility is thus evident.

\section{CONCLUSION}

The study reveals that if food accessibility, which is an important component of food security, is measured in terms of the threshold determined by the MPCE on food as per the minimum food basket for rural India, set by the Planning Commission in 2014 and adjusted by the latest consumer price index, $15.33 \%$ of the households do not have food access in the three villages of Bolpur-Sriniketan block of the district of Birbhum, West Bengal. The situation of insecure food access is faced by households with zero operational land and marginal farmers who constitute $86 \%$ of our sample population, which is drawn in proportion to their share in total population. Insecurity in terms of food access is found to be the highest among the ST followed by SC and GC. All households from OBC category have food accessibility.

This study also makes an attempt to analyse food accessibility in terms of another threshold, viz., the mean MPCE of rural West Bengal measured by NSSO in 2011, adjusted by the latest consumer price index. According to this measure, MPCE on food of $53.33 \%$ of households fall below the mean of that of rural West Bengal in the respective villages. Moreover, across the land size classes, only semimedium, medium and big farmers are secured in terms of food access. There exists an inverse relation between land size and head-count ratio of household's food accessibility. It is quite alarming to find that $76.19 \%$ of ST, $57.89 \%$ of SC and more than $23 \%$ of General caste households do not have food access under this threshold.

An in-depth probing on the source of income of the households points out that there exists (i) a negative relation between wage income and food accessibility, (ii) an inverse relationship between income generated from farm activity and household's food accessibility and (iii) a positive relation between income from regular service, trade, business and food accessibility. Thus food accessibility primarily depends on the nature as well as quality of one's employment.

On the whole, the total picture of households' food accessibility is gloomy in the sample villages of Bolpur -Sriniketan block of the district of Birbhum, in spite of the fact that the cropping intensity is higher in the block in comparison to that of the district's average. In this scenario, access to sustainable employment opportunities for the poor can be the only solution for achieving 'Zero Hunger by 2030 ', rather than by mere access to subsidized rice and wheat, supplied through public distribution system (PDS). There should be proper implementation and regular monitoring of all programmes initiated by the government to educate the rural masses for developing their skills. In addition to that, there should be the provision of social security as a back-up against entitlement failures within society for the poor.

\section{REFERENCES}

Abu, G.A. and Soom, A. 2016. 'Analysis of Factors Affecting Food Security in Rural and Urban Farming Households of Benue State,Nigeria', International Journal of Food and Agricultural Economics, 4(1), Special Issue: 55-68.

Ahmed, U.I., Ying, L., Bashir, M.K., Abid, M. and Zulfiqar, F. 2017. 'Status and determinants of small farming households' food security and role of market access in enhancing food security in rural Pakistan.' PLOS ONE, 12(10): e0185466, p1-15.

Appleton, S. 1999. 'Women Headed Households and Household Welfare: An Empirical Demonstration for Uganda', World Development, 24(12): 1811-1827.

Directorate of Census Operations, West Bengal (2011) District Census Handbook Birbhum.

Dutta, I. and Gundersen, C. 2007. 'Measures of Food Insecurity at the Household Level', in B. Guha-Khasnobis, S.S. Acharya and B. Davis (ed) Food Security Indicators, 
Measurement, and the Impact of Trade Openness, Oxford University Press: New York, pp. 45-48.

Foster, J., Greer, J. and Thorbecke, E. 1984. 'Notes and Comments: A Class of Decomposable Poverty Measures'. Econometrica, 52: 761-765.

Government of India Ministry of Statistics and Programme Implementation \& National Statistical Organisation (2013) Perceived Adequacy of Food Consumption in Indian Households NSS $66^{\text {th }}$ Round. National Sample Survey Office, February, pp. 13.

Government of India. 2014. Report of the Expert Group to Review the Methodology for Measurement of Poverty. Planning Commission, June, pp. 3.

Government of India Ministry of Statistics and Programme Implementation \& National Statistical Organisation. 2014. Household Consumption of Various Goods and Services in India 20ll-12. National Sample Survey Office, June.

Guja, M.M. 2012 ‘Household Food Security Status and Coping Strategies in Humbo Wereda, Snnprs, Ethiopia.' International Journal of Sciences: Basic and Applied Research, 6(1): 69.

International Food Policy Research Institute. (2017) 2017 Global Hunger Index. Concern Worldwide, Welthungerhilfe, Washington, DC, October.

Jabo, M.S.M., Ismail, M.M., Shamsuddin, M.N., Abdullah, A.M. and Maikasuwa, A.M. 2014. 'Examining the Incidence, Depth and Severity of Food Insecurity among rural Households in Nigeria'. Journal of Economics and Sustainable Development, 5(26): 32-41.

Karmakar, S. and Sarkar, D. 2014. 'Income Inequality, Poverty and Food Security in West Bengal, India'. Journal of Social Science Studies, 1(1): 34-35.

Muche, M., Endalew, B. and Koricho, T. 2014. 'Determinants of Household Food Security among Southwest Ethiopia Rural Households', Food Science and Technology, 2(7): 93-100.

MS Swaminathan Research Foundation and The World Food Programme. 2002. Food Security Atlas of Urban India, M S Swaminathan Research Foundation, Chennai.

MS Swaminathan Research Foundation and The World Food Programme. 2008. Report On The State Of Food Security In Rural India, M S Swaminathan Research Foundation, Chennai.

Menon, P., Deolalikar, A. and Bhaskar, A. 2009. India State Hunger Index Comparisons of Hunger Across States, IFPRI, Welthungerhilfe, UC Riverside, Washington, D.C., Bonn, and Riverside, February.
Orewa, S.I. and Iyangbe, C.O. 2009. 'The Food Insecurity Profile among the Rural and Low-Income Urban Dwellers in Nigeria'. American-Eurasian Journal of Scientific Research, 4(4): 302-307.

Robert, A., James, O.M. and Thomas, T. 2013. 'Determinants of Household Food Security in the Sekyere-Afram Plains District of Ghana', $1^{\text {st }}$ Annual International Interdisciplinary Conference, 24-26 April, Azores, Portugal - Proceedings: 516.

Roy, D. and Sen, M. 2010. 'Poverty, Hunger and Public Action'. Loka Kalyan Parishad, Kolkata.

Sajjad, H. and Iffat, N. 2014. 'Food Security in Rural Areas of Vaishali District, India: A Household Level Analysis'. European Journal of Sustainable Development 3(3): 235-250.

Sen, A. 1976. 'Poverty: An Ordinal Approach to Measurement'. Econometrica, 44: 219-31.

1981. Poverty and Famines: An Essay on Entitlement and Deprivation. Oxford University Press: New Delhi, pp. 1.

1987. 'Africa and India: What do we have to learn from each other?' WIDER Working Papers 19, World Institute for Development Economics Research, Helsinki, August, p6.

The UN World Food Programme and Institute for Human Development. 2008. Food Security Atlas of Rural Chhattisgarh. New Delhi.

The UN World Food Programme and Institute for Human Development. 2008. Food Security Atlas of Rural Orissa. New Delhi.

The UN World Food Programme and Institute for Human Development. 2009. Food Security Atlas of Rural Bihar. New Delhi.

The UN World Food Programme and Institute for Human Development. 2010. Food Security Atlas of Rural Uttar Pradesh. New Delhi.

United Nations. 1975. Report of The World Food Conference, Rome, November 5-16, 1974, New York.

United Nations Universal Declaration of Human Rights 1948. 1949. United Nations, pp. 5-6.

World Bank. 1986. Poverty and Hunger: Issues and Options for Food Security in Developing Countries, World Bank Policy Study, Washington D.C.

https://www.un.org/sustainabledevelopment/sustainabledevelopment-goals. 